\title{
The Air-Conditioning Energy Savings Achieved by Application of Time- Predicted Driven Night Ventilation
}

\author{
Maja Todorović \\ Assistant Professo \\ University of Belgrade \\ Faculty of Mechanical Engineering
}

This paper analyses the influence of time-predicted night ventilation applied during the summer season on the total energy consumption of airconditioning system. Analysis has been made on the basis of a computer program for dynamic simulation of air-conditioned rooms thermal behavior. The program was developed at the Department for Thermal Engineering at the Faculty of Mechanical Engineering, University of Belgrade. Air-conditioning operating modes without and with application of night ventilation, and different periods of night ventilation are analysed. Cooling loads, fan energy consumption and overall energy consumption for summer conditions for Belgrade for the whole cooling season are given. The obtained results were compared, and hereupon a review is given of the energy savings for the whole cooling season.

Keywords: Air-conditioning, Night ventilation, Energy consumption, Cooling load reduction, Energy savings.

\section{INTRODUCTION}

In order to investigate the influence of night ventilation technique on total energy savings of air-conditioning system, operating modes are simulated for a typical airconditioned room, operating mode without night ventilation and different modes with application of time-driven night ventilation, where the period of night ventilation was varied. Simulation has been aided by a computer program for dynamic simulation of airconditioned rooms thermal behaviour, which was developed at the Department for Thermal Engineering at the Faculty of Mechanical Engineering in Belgrade [1]. The program, written in $\mathrm{C}$ language, which operates under Windows operating system, is based on a detailed mathematical model of non-steady state heat transfer in an air-conditioned space [2].

\section{THE AIR-CONDITIONED ROOM MODEL AND SIMULATION PROGRAM}

The analysed air-conditioned room is considered to be typical of residential or commercial buildings. Its shape, dimensions, construction and position are in common with many rooms in a multi-story building. The building is in an open position, with no objects nearby; therefore its windows are not shaded. Internal dimensions of the room are 5 by 4 by $2.6 \mathrm{~m}$. Its double-glazed window in the facade wall measures are 2.4 by $1.5 \mathrm{~m}$. Facade wall is insulated, and its $U$-value is $0.8 \mathrm{~W} / \mathrm{m} 2 \mathrm{~K}$. The Wooden 1 by $2 \mathrm{~m}$ door is in a facade-facing wall, leading into the central corridor. All other surfaces are adjacent to the air-conditioned spaces.

Mathematical model of non-steady state heat transfer consists of a system of equations that describes

Received: October 2012, Accepted: January 2014

Correspondence to: Maja Todorovic

Faculty of Mechanical Engineering,

Kraljice Marije 16, 11120 Belgrade 35, Serbia

E-mail: mtodorovic@mas.bg.ac.rs

doi:10.5937/fmet1402161T

(C) Faculty of Mechanical Engineering, Belgrade. All rights reserved convection, conduction and radiation, and includes appropriate boundary and initial conditions [2].

The simulation program is universal for any input data: the type of construction of room elements, dimensions of window and door and its position, room orientation, weather data, air-conditioning operating mode, indoor air temperature set-up, lighting set-up, night ventilation set-up, etc (Figure 1).

After the start of the simulation program, a window opens with the Main menu. A click on the "Start Calculation", opens the windows for entering the initial data for calculation (Figure 1). Through the first window "Initial data for calculation" following values are entered: calculation time step, the initial hour, the length of calculation (you can specify one or more days), initial temperature, desired indoor air temperature, etc. It also sets the time schedule for airconditioning system during the day, the time schedule for lighting and night ventilation during the night. The total flow of fresh air into the system is defined by the number of air changes per hour. After confirming the entered data, click on the OK button opens the next window that defines weather data. Calculation can be performed for design conditions or for the whole season using data on typical meteorological year [3]. Data on typical meteorological year are loaded as an input file. Window "Geometry" refers to the geometry of the model-room, ie, to define the size of the room, the location and size of windows and doors and the position of the bulb in the room. Upon confirmation of input data on the geometry of the room, the program starts calculation. When it reaches the set time, a notice "The end of calculation" appears

The task of optimization of air-conditioning systems is to find the operating range in a way to obtain minimum power consumption for the air preparation and distribution. The energy that air-conditioning system consumes is needed for cooling the interior space (the elimination of cooling load), for fresh air treatment, and the electric motors for actuating the intake and exhaust fans. 


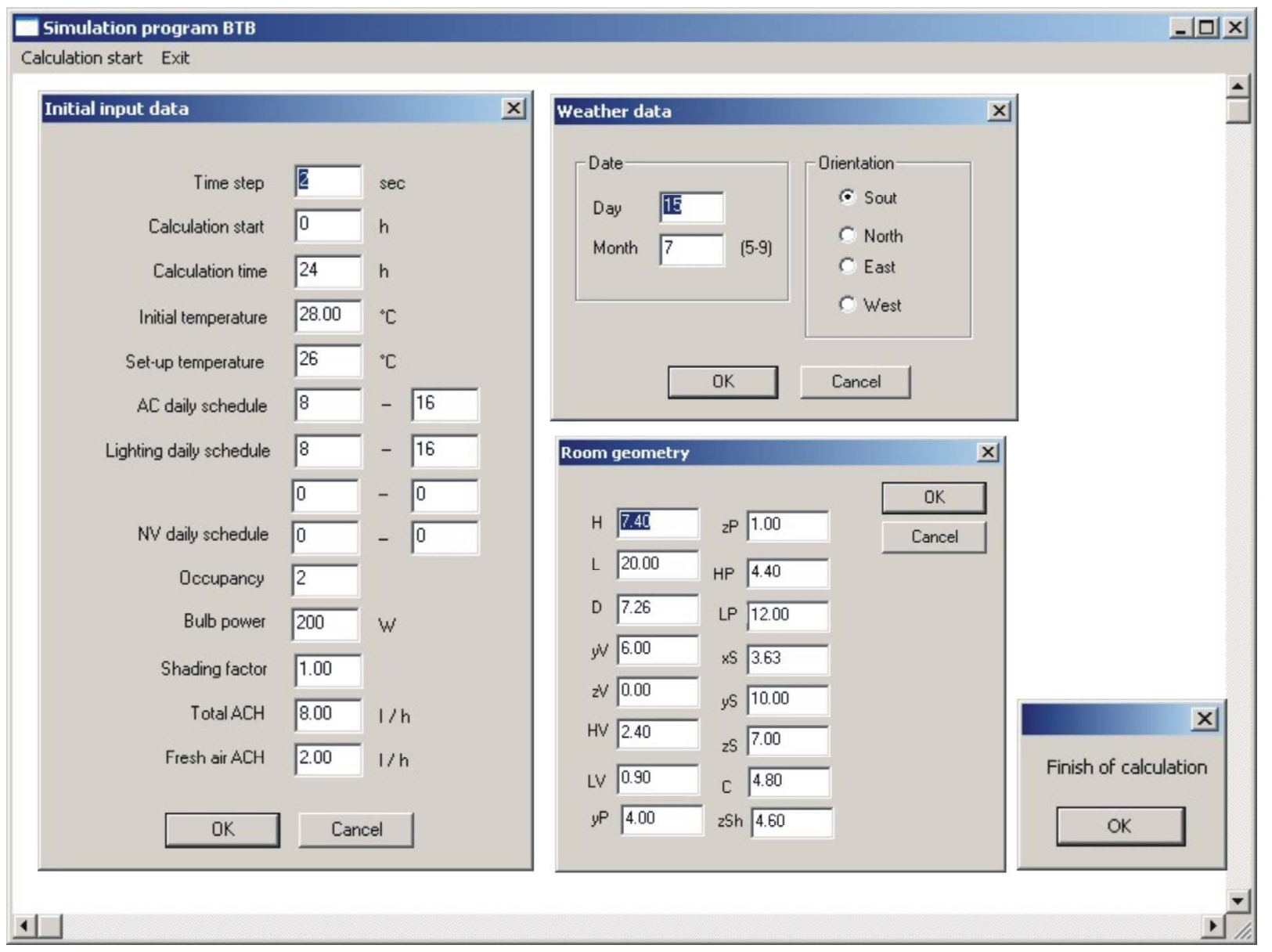

Figure 1. Simulation program for air-conditioned rooms thermal behaviour - Dialogs for input data

Therefore, the objective function, in this case, is the total electricity consumption $[\mathrm{kWh}]$ of air-conditioning system. The additional condition is that, at the optimal mode, comfort conditions are met during the period of occupancy of the building. A method for optimizing is single-criterion, with its required minimum value. The objective function - total energy consumption for airconditioning is expressed as:

$$
P(\tau)=\int_{0}^{\tau} Q_{c l}(\tau) \cdot d \tau+\int_{0}^{\tau} Q_{f a}(\tau) \cdot d \tau+\int_{0}^{\tau} p_{f a n}(\tau) \cdot d \tau(1)
$$

The energy required for cooling is reduced to a unit of electricity, so the cooling load is divided by the COP (Coefficient Of Performance) making it possible to add all three members of the equation (1). Cooling load is calculated from the heat balance and refers to the amount of heat transferred to the indoor air:

$$
Q_{c l}(\tau)=\left(\sum_{i=1}^{n} h_{i} A_{i}\left[\vartheta_{i}(\tau)-\vartheta_{\text {ia }}(\tau)\right]+b_{\text {lig }} Q_{\text {lig }}(\tau)\right) \cdot \frac{1}{C O P}
$$

The energy needed for fresh air treatment is depending on the proportion of the fresh air in the total air flow and the difference of the external and the internal air temperature:

$$
Q_{f a}(\tau)=\left[m_{f a} \cdot \dot{V} \cdot \rho \cdot c_{P} \cdot\left(\vartheta_{f a}(\tau)-\vartheta_{i a}(\tau)\right)\right] \cdot \frac{1}{C O P}(3)
$$

Electricity consumption for the fan drive is calculated as a product of fan engine power and operating time:

$$
P_{\text {fan }}(\tau)=p_{e l} \cdot \tau
$$

Introducing mechanical night ventilation results in significant cooling load decrease, but also in increased electricity consumption for fan operation during the night, when ventilation is applied.

\section{SIMULATION OF THE ROOM THERMAL BEHAVIOR FOR AND APPLICATION OF NIGHT VENTIALTION}

In order to investigate the influence of the time-driven night ventilation on the total energy consumption, operating schedules are simulated of the airconditioning system without and with night ventilation:

- The duration of night ventilation was varied for the air-conditioned space for a typical mediumheavy type of construction oriented to the south, the air-conditioning mode from 8-16 h;

- Weather data used are for the typical meteorological year for Belgrade;

- The technique of time-driven mechanical night ventilation was applied;

- Variation of night ventilation during the night from 1 to 8 hours. 

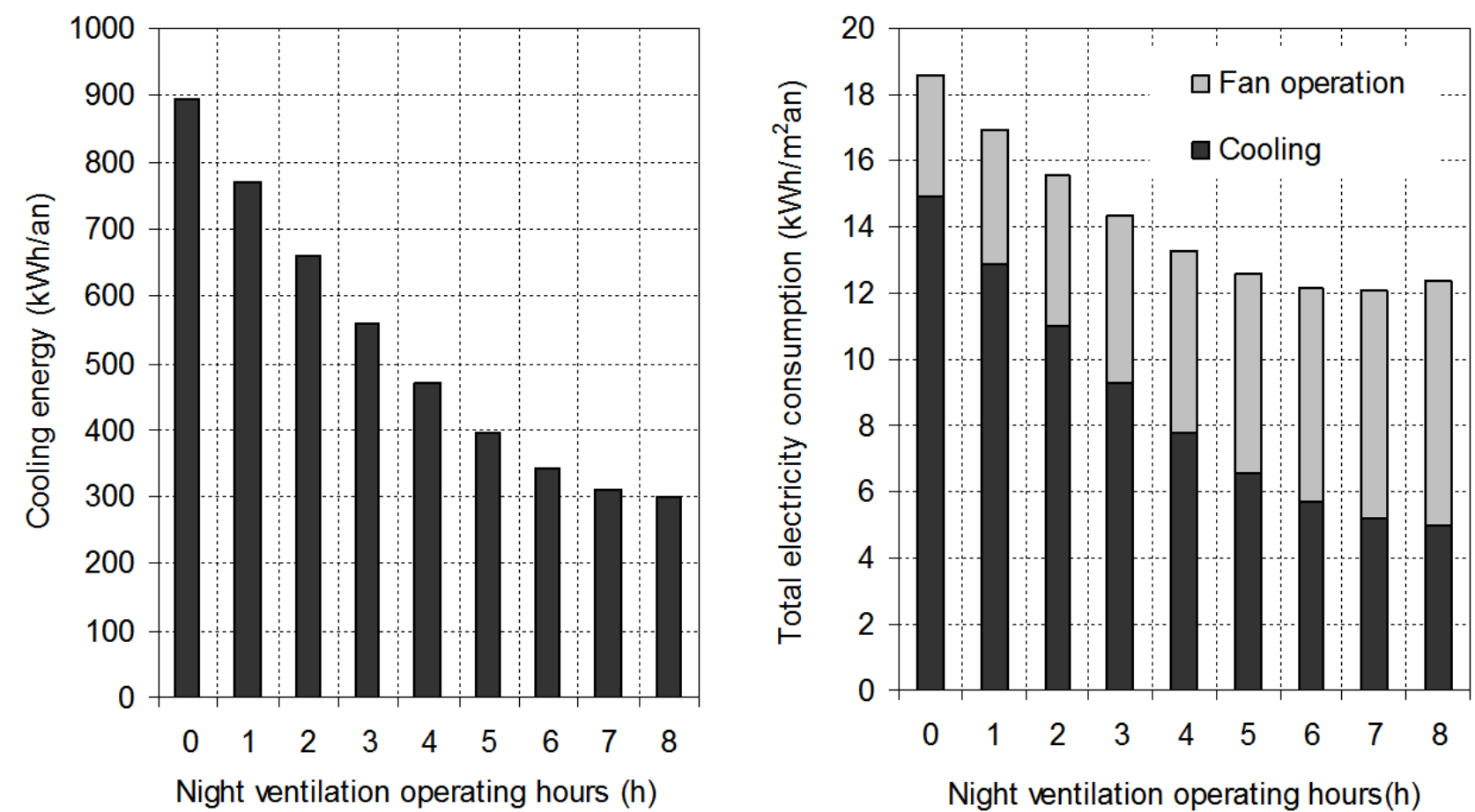

Figure 2. Decrease in cooling load and total energy consumption of the air-conditioning system by application of time-driven mechanical night ventilation

The results for cooling load decrease and total energy consumption of the air-conditioning system, included fan operation during mechanical night ventilation, are shown in Figure 2.

The results shown in Figure 2. (diagram on the left) indicate cooling load for the period of cooling season, and different operating schedules of time-driven night ventilation, for south oriented air-conditioned room. It is obvious that introducing the technique of mechanical night ventilation can significantly reduce the cooling load. The period of night ventilation included periods during the night when the lowest outside temperatures occur. By increasing the duration of night ventilation, the cooling load is reduced.

Analyzing the results of total energy needed for the system operation (Figure 2 on the right) it can be seen that the optimal duration of the night ventilation is seven hours during the night.

The comparison between operating schedule without night ventilation and with seven hours time-driven mechanical night ventilation is given in Figure 3. The energy savings in cooling energy are great and amount to $65 \%$ on annual basis. On the other hand, energy needed for fan operation is growing with the increase of number of hours of the mechanical night ventilation operation. In the case of 7 hours night ventilation during each night of the cooling season, total electricity consumption is reduced by $34 \%$.

The simulation results have proved that application of the night ventilation leads to an decrease of the daily cooling load peak, as well as decrease of the daily energy needed for cooling. Once the air-conditioning system is shut down, the indoor air temperature starts rising, on account of walls cooling, until thermal equilibrium is reached. Since there are no conditions for heat to be transferred to the indoor air (due to the fact that air-conditioning system does not eliminate warm air from the room), a certain amount of heat is stored in the building envelope. The next day, when the airconditioning system is started, the indoor air temperature starts dropping, thus enabling heat transfer. But, at that moment, the cooling load value is higher than the previous day, because of the superposed heat gain and the heat stored inside the walls. Contribution of night ventilation is crucial for enabling heat transfer of stored heat to ventilation air during the night.

For efficient use of night ventilation, the key parameter is the temperature of outside air during the night. This parameter determines the extent to which the external environment can act as a heat sink and receives a certain amount of heat stored in the building envelope during the day. The effect of the heat sink is determined, therefore, by the temperature difference between the indoor and outside air. Another very important parameter is the air flow for night ventilation.

Cooling efficiency using night ventilation is generally based on the value of the flow of ventilation air. Using mechanical ventilation, the air flow can be controlled.

On the other hand, the change of outside air temperature during the season is stochastic variable. As mentioned earlier, the value of the temperature difference of external and internal air determines the cooling potential. For this reason, the contribution of the night ventilation differs during the season, which can be seen from the diagram in Figure 4, showing average daily cooling load decrease during five months of the cooling season. 


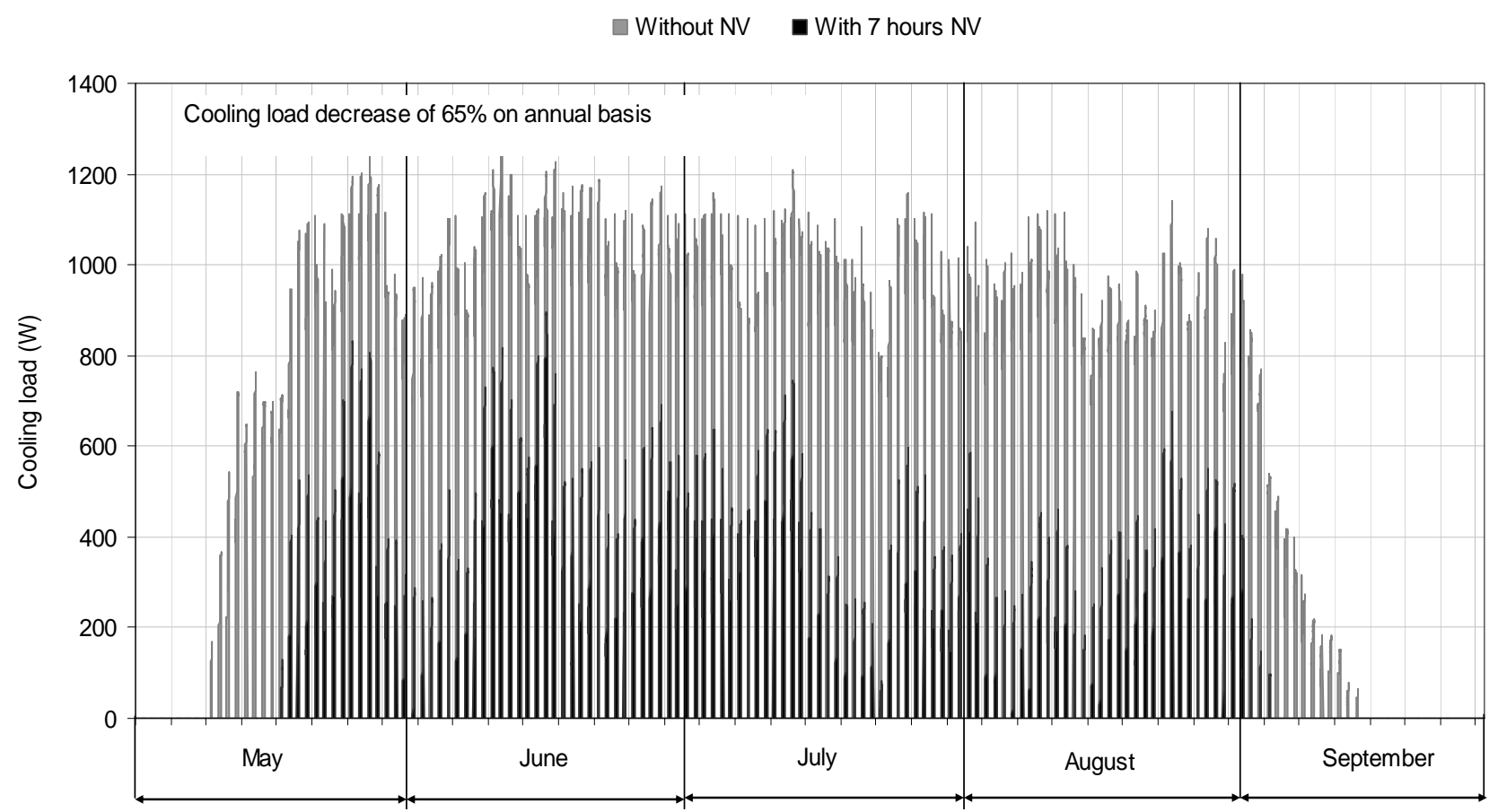

Figure 3. Cooling load for south oriented air-conditioned room under operating schedules without and with application of seven hours time-driven mechanical night ventilation

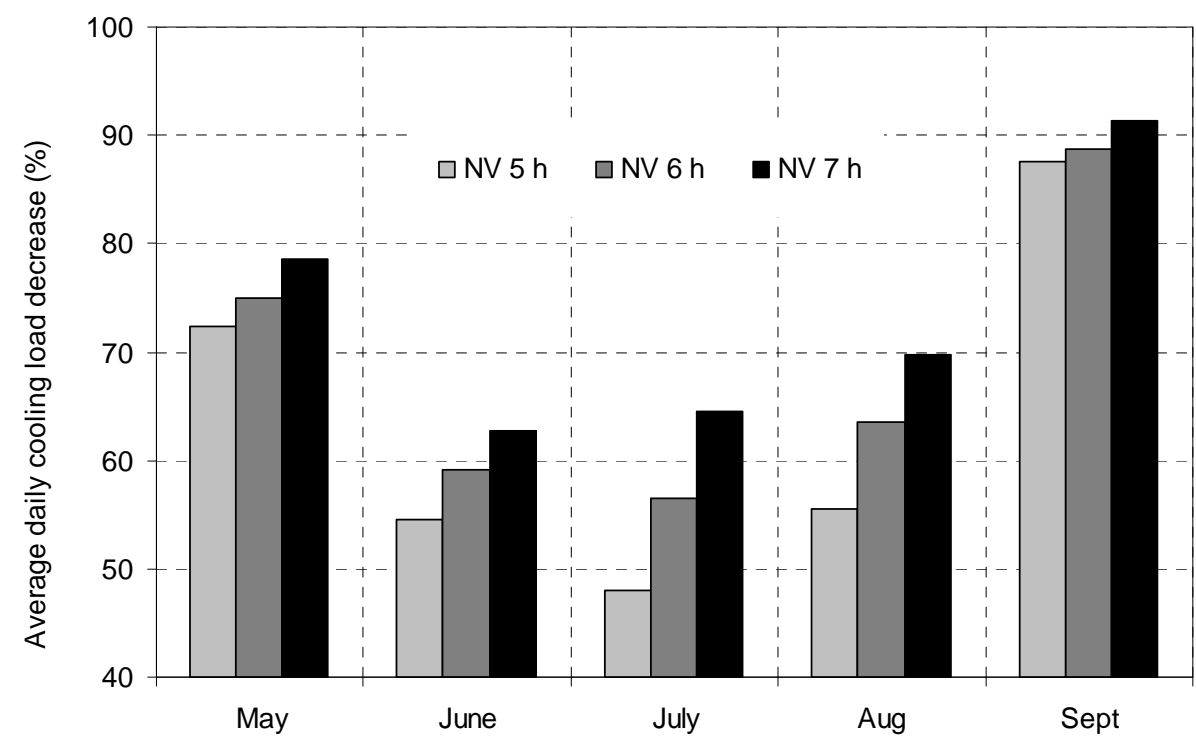

Figure 4.Average daily cooling load decrease depending on night ventilation operating hours

From the diagram shown in Figure 4. it is evident that night ventilation contribution is higher at the beginning and at the end of the season, which results from lower outdoor air temperatures. But, it is also important to notice that night ventilation operating hours play a significant role during the high season. In other words, the increased number of operating hours affects efficiency of night ventilation during high season, while in the transitional periods (May and September) it is of less importance. This observation leads to the conclusion that 7 hours of night ventilation operation is not optimal for the whole season. A better solution is to apply time-predicted driven night ventilation. Time-predicted driven night ventilation introduces a variable number of operating hours during each night, depending on the weather forecast.

\section{THE APPLICATION OF TIME-PREDICTED DRIVEN NIGHT VENTIALTION}

Considering that outside air temperature changes throughout the season, meaning that warmer and colder periods appear, it is proposed to introduce a time-driven night ventilation with prediction, and to optimize operating conditions, which leads to reduction of total energy consumption. Diagram on Figure 5 shows the influence of night ventilation operating hours on cooling load decrease during warmer and colder periods. 


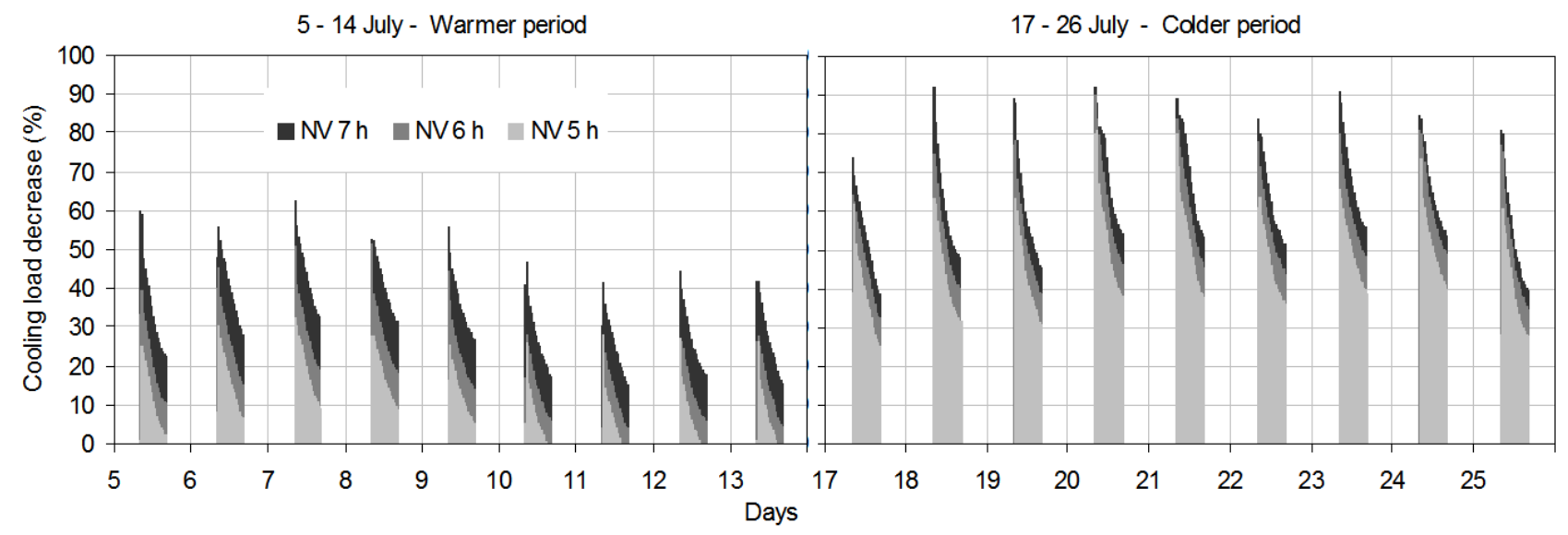

Figure 5. Cooling load decrease during warmer and colder periods in dependence of night ventilation operating hours

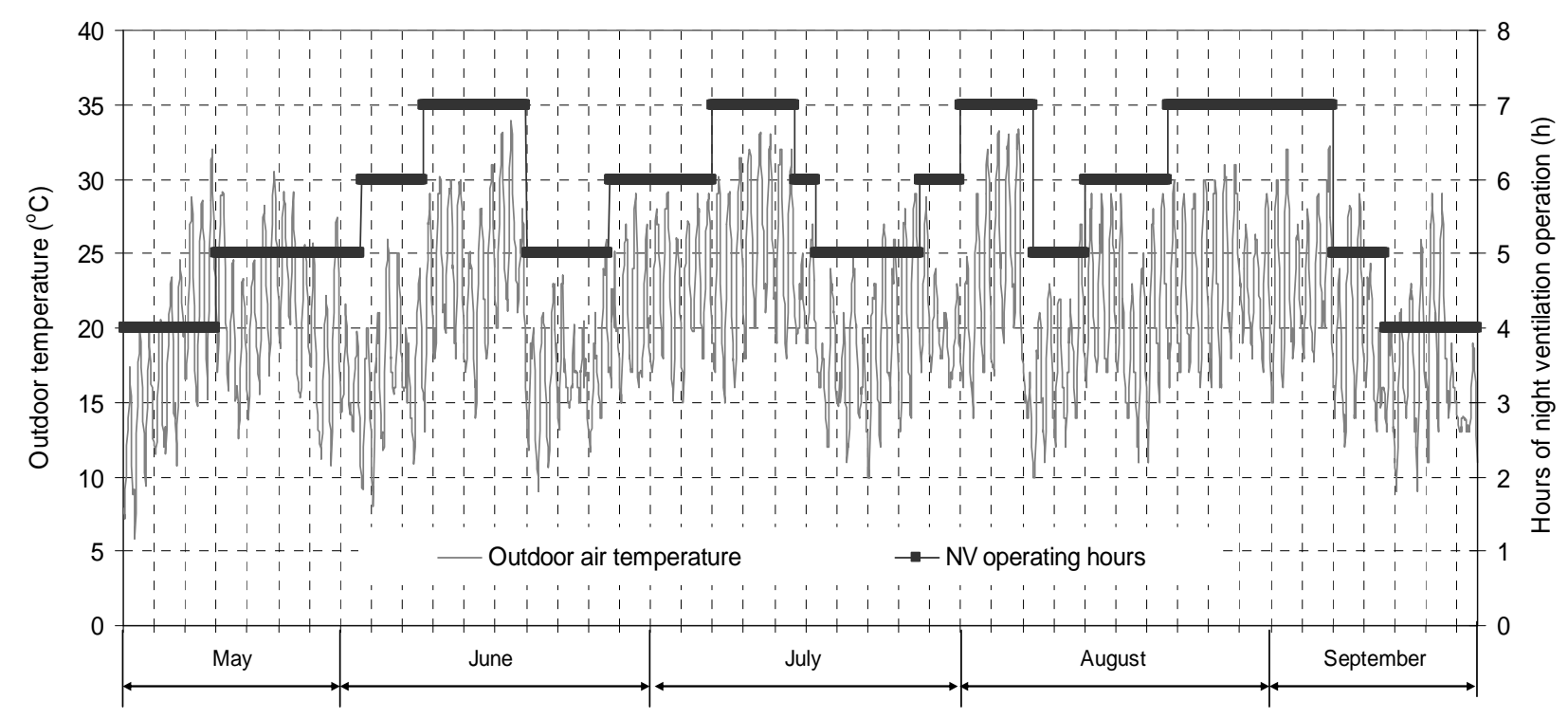

Summer season

Figure 5. Time-predicted night ventilation for the cooling season for typical meteorological year for Belgrade

The analysis of different night ventilation operating hours during warmer period of summer leads to the following conclusions: the contribution of night ventilation in lowering the cooling load is smaller, due to the high value of external air temperature, both during day and night hours, but the number of night ventilation operating hours significantly affect the reduced cooling load. During colder periods, the increased number of night ventilation operating hours does not contribute to a significant reduction of cooling load, which can be seen from the diagram in Figure 5 .

Since energy consumption for fan operation is directly proportional to the number of operating hours, the aim is to decrease total number of fan operating hours during the whole season.

Diagram shown in Figure 6 gives the recommended number of night ventilation operating hours, using weekly weather forecast. The time-predicted operating schedule can be set in advance, once a week, using the Building Management System.

Data presented on Figure 6 correspond to typical meteorological year for Belgrade. By introducing time- predicted operating schedule of night ventilation, fan operating hours are reduced by $168 \mathrm{~h} / \mathrm{an}$, without affecting the cooling load decrease. Compared to operating regime with the constant seven hours night ventilation, additional total energy saving of $4 \%$ is achieved.

\section{CONCLUSION}

This paper analyses the influence of time-predicted night ventilation applied during the summer season on the total energy consumption of air-conditioning system for Belgrade weather conditions. The simulation program used for the analysis has been developed at the Department for Thermal Engineering at the Faculty of Mechanical Engineering, University of Belgrade [2].

In order to optimize overall energy consumption, it is necessary to reduce energy consumption for room cooling by enabling the room envelope cooling during the night. Optimum energy consumption can be achieved by introducing the night ventilating (without 
outdoor air treatment) along with the room cooling during the period of room occupancy.

Analysed air-conditioning operating modes without and with application of night ventilation have shown that significant energy savings can be obtained if night ventilation is introduced. By applying time-driven night ventilation with constant number of operating hours during the night, throughout the whole summer season, the optimum in total energy savings is reached for 7 hours of night ventilation schedule. The total energy savings amount to $34 \%$ on annual basis. Time-predicted night ventilation introduces a variable number of operating hours during each night, depending on the weather forecast. The application of time-predicted night ventilation leads to greater total energy savings on annual basis and amounts to $38 \%$.

\section{NOMENCLATURE}

$b_{\text {lig }}[-] \quad$ fraction of heat transfer from lighting bulb via convection,

COP [-] coefficient of performance of chiller,

$c_{p} \quad[\mathrm{~J} / \mathrm{kg} \mathrm{K}]$ air specific capcaity,

$h \quad\left[\mathrm{~W} / \mathrm{m}^{2} \mathrm{~K}\right]$ heat transfer coefficient,

$m_{f a} \quad[\mathrm{~kg}]$ mass of fresh air,

$n \quad[\mathrm{~h}]$ number of operating hours,

$P \quad[\mathrm{kWh}]$ electricity consumption,

$p_{\text {fan }} \quad[\mathrm{W}]$ installed fan power,

$Q_{C l} \quad[\mathrm{~W}]$ cooling load,

$Q_{f a} \quad[\mathrm{~W}]$ amount of heat for fresh air treatment,

$Q_{\text {lig }} \quad[\mathrm{W}]$ amount of heat transferred from lighting,

$V \quad\left[\mathrm{~m}^{3}\right]$ room volume,

$\dot{V} \quad\left[\mathrm{~m}^{3} / \mathrm{h}\right]$ flow rate,

$\rho \quad\left[\mathrm{kg} / \mathrm{m}^{3}\right]$ air density,

$\vartheta_{i} \quad\left[{ }^{\circ} \mathrm{C}\right]$ inside surface temperature,

$\vartheta_{\text {ia }} \quad\left[{ }^{\circ} \mathrm{C}\right]$ inside air temperature,

$\vartheta_{f a} \quad\left[{ }^{\circ} \mathrm{C}\right]$ fresh air temperature,

$\tau \quad[\mathrm{s}]$ time.

\section{REFERENCES}

[1] Todorović, M., Živković, B., Banjac, M. and Švarc, B.: Simulation program for analysis of dinamic thermal behavior of buildings, University of Belgrade, Faculty of Mechanical Engineering, 283/2, 2009.
[2] Todorović, M.: Optimization of air-conditioning system energy consumption by applying night ventilation, $\mathrm{PhD}$ Thesis, University of Belgrade, Faculty of Mechanical Engineering, 2007. (in Serbian)

[3] Typical meteorological year for Belgrade, available at:http://www.eere.energy.gov/buildings/energyplus /weather_data.cfm

[4] Todorović, M. and Živković B.: Numerical simulation of air-conditioned rooms' thermal behavior dynamics, $14^{\text {th }}$ Symposium of Thermal Engineers Society of Serbia, Proceedings on CD, Soko Banja, 2009.

[5] Todorović, M. and Bajc, T.: The influence of the regimes of use of building on total building energy consumption, Regional Conference IEEP 2011, Proceedings on CD, Kopaonik, Serbia.

[6] Florides, G.A., Tassou, S.A., Kalogirou, S.A. and Wrobel L.C.: Measures used to lower building energy consumption and their cost effectiveness, Applied Energy Vol. 73, pp. 299-328, 2002

[7] Geros, V., Santamouris, M., Karatasou, S., Tsangrassoulis, A. and Papanikolau, N.: On the cooling potential of night ventilation techniques in the urban environment, Energy and Buildings Vol. 37, pp.243-257, 2005.

[8] Pfafferott, J., Herkel, S. and Wambsgans, M.: Design, monitoring and evaluation of a low energy office building with passive cooling by night ventilation, Energy and Buildings Vol. 36, pp. 455465, 2004.

\section{УШТЕДА ЕНЕРГИЈЕ КЛИМАТИЗАЦИОНОГ СИСТЕМА ПРИМЕНОМ ВРЕМЕНСКИ ВОЪЕНЕ НОЪНЕ ВЕНТИЛАЦИЈЕ СА ПРЕДВИЪАЊЕМ}

\section{Маја Тодоровић}

У раду је приказан утицај примене временски вођене ноћне вентилације са предвиђањем током летњег периода на укупну потрошњу енергије климатизационог система. Анализа је спроведена на основу компјутерског програма за динамичку симулацију термичког понашања климатизоване просторије. Програм је развијен на Катедри за термотехнику Машинског факултета, Универзитета у Београду. Анализирани су режими рада система за климатизацију када се не примењује ноћна вентилација и режими са применом ноћне вентилације са различитим временским трајањем. Приказани су токови топлотних оптерећења и енергије потребне за рад система, за целу летњу сезону. Добијени резултати симулације су упоређени и дати су предлози за уштеду укупне енергије коју троши систем за климатизацију. 